Renata PRZYGODZKA, PhD, Professor of the University of Bialystok

Faculty of Economics and Finance, University of Bialystok

e-mail: r.przygodzka@uwb.edu.pl

ORCID: 0000-0003-0488-8097

DOI: $10.15290 /$ oes.2020.04.102.07

\title{
THE SPECIFICITY OF STATE AID IN POLAND IN COMPARISON WITH EUROPEAN UNION COUNTRIES ${ }^{1}$
}

\begin{abstract}
Summary
Purpose - The aim of the paper is to identify the directions and instruments of state aid (with the exception of agriculture and the transport sector) used in Poland and to identify their specificities in relation to other countries of the European Union.

Research method - The achievement of the above purpose required the use of research methods such as the analysis of legal acts, the collection and analysis of secondary data and the processing of the collected factual material using descriptive statistical methods. The data source was The State Aid Scoreboard, together with a variety of reports from the Office for Competition and Consumer Protection.

Results - In 2017, the amount of state aid in Poland was twice as high as the average indicator in the European Union $(1.51 \%$ and $0.76 \%$ respectively). Regional development $(27.3 \%)$ was the main beneficiary of its allocation, while environmental protection was $55.4 \%$ in the EU. A specific feature of state aid in Poland is its sustainability, which does not exist to a similar extent in other Member States.

Originality / value - According to the author's knowledge, this is one of the unique research papers devoted to the problem of state aid, especially in the context of the indication of the specific characteristics of state aid in Poland against the background of the countries of the European Union.
\end{abstract}

Keywords: state aid, Poland, European Union

JEL Classification: E62, H81, K21

\section{Introduction}

In contemporary market economies and also in more liberal ones, the role of the state extends considerably beyond the role of a "night watchman" that is assigned by classical economists. Increasing awareness of the imperfections of market mechanism as the allocator of limited economic resources resulted in expanding the state activity into numerous other areas. Therefore, the state not only establishes the law, but is also involved in the production and supply of goods and services (more

1 Article received on 24 March 2020, accepted on 29 May 2020. 
frequently not only the public ones), is the acquirer of goods made by the market sector, is involved in the redistribution of income and has influence on the behaviours of businesses by means of regulations and interventions [Kogut-Jaworska, 2016, pp. 188-189; Przygodzka, 2009, pp. 60-61].

In the European Union (similarly to Poland) the leading role in the process of creating economic growth and the functioning of the economy, was attached to the mechanism of market competition, which is clearly visible both in the Treaty on the European Union [TUE, 2016, Preamble, art. 3], the Treaty on the Functioning of the European Union [TFUE, 2016, art. 107] and in the Constitution of the Republic of Poland [1997, art. 20 and 22]. Thus, "any aid granted by a Member State or through State resources in any form whatsoever, which distorts or threatens to distort competition by favouring certain undertakings or the production of certain goods shall, in so far as it affects trade between Member States, be incompatible with the internal market" [TFUE, 2016, art. 107]. Simultaneously, owing to various conditionings the state is allowed to intervene, but the only competence in terms of establishing the rules of competition necessary for the functioning of domestic market was given to the European Union [TFUE, 2016, art. 3]. As compliant with the domestic market there are (or may be) considered, among others: social aid, the aid connected with neutralising the effects of extraordinary events, the aid dedicated to fostering economic development of regions in difficult social and economic situations, the aid allocated to supporting the realisation of important projects of mutual European interest or aimed at addressing serious disturbances in the economy of a member state. The EU regulations specifying the recommendations related to the admissibility of state aid are constantly changing and are adapting to the changing conditionings on a global and regional scale as well as the conditions within member states. However, importantly, to a constantly larger degree (within the so-called block exemptions) they enable member states to select in a more flexible way both the directions of the state aid being used and instruments (by means of which it is realised), which is connected with the diversification of public policies in those states [Rezolucja..., 2013].

In this context it is interesting whether (and if so) to what degree the state aid used by the Polish government towards businesses is similar or different from the aid realised in other European Union countries.

Therefore, the aim of this paper is to identify the directions and instruments of state aid (apart from agriculture and the transport sector) used in Poland and to indicate their specific character against the background of all other countries of the European Union. Furthermore, the paper attempts to verify the following thesis: the dimension, allocation and the state aid instruments used in Poland are different in comparison with other EU Member States.

The realisation of the aim and the verification of the thesis required the application of such research methods as: the analysis of legal acts, the analysis of secondary data as well as the processing of the accumulated factual material by means of descriptive statistical methods. The sources of data were: State Aid Scoreboard (SCB, i.e. the database based on the information from the reports on the 
provided state aid that was submitted by EU member states to the European Commission) and the reports from the Office for Competition and Consumer Protection which supervises the compliance of the method state aid is distributed in Poland (with the exception of agriculture) with both EU and domestic law. The time range of the research comprises the years 2014-2017 and is justified by changes in the regulations related to the admissibility of state aid that were implemented in 2014 including the new financial perspective and the fact that the data included in the base (during the research realisation) concerned the year 2017.

\section{The scope of state aid}

In accordance with the State Aid Scoreboard 2018 method, that data included in the base comprises the expenditure of Member States which was related to all existing aid measures for industry, services (since 2014 also in terms of the renewable energy programs), agriculture, fishing and transport with reference to which the European Commission adopted a formal decision or received application from member states as the measures eligible for exemption under the regulation on block exemptions (GBER), the decree on block exemptions in agriculture (ABER) or the decree on block exemptions in the fishing and aquaculture sectors [The State..., 2018]. Significantly, this aid does not include the measures serving the financing of the services provided in the public interest. These are services which are classified by the public authorities of member states as the services that serve the general interest - therefore, there is special public obligation to offer them [Guide to the application..., 2013]. They comprise: the services provided in the general economic interest (e.g. waste management, postal services), services of noneconomic character (e.g. the police, the judicial system) and social services provided in general interest. The calculations included in the base do not include the expenditures on the aid specified as de minimis. It is a particular category of support provided by a state because it is believed that owing to its small value it does not disrupt competition in the EU dimension [Act, 2013] $]^{2}$. The statistics concerning state aid separately include the expenditure on the support for public transport and railways. The analysis shown below does not include the expenditure (similarly to the situation in agriculture). It should also be stressed that the figures quoted in the reports submitted by member states are only an estimation, while the basis for calculating the value of state aid is the so-called economic benefit transferred to enterprises by means of public resources or either the cost or loss of income for public authorities. They may be estimated in several ways: in the case of subsidies the advantage granted to the beneficiary usually corresponds to the budget

\footnotetext{
2 It should also be pointed out that in Poland in 2017 the value of de minimis aid amounted to $€ 1.6 \mathrm{bln}$ $(0.34 \%$ GDP), i.e. it constituted approx. $25 \%$ of the total value of state aid [Raport o pomocy de minimis..., 2018, p. 7].
} 
expenditure. Whereas in case of other aid instruments the advantage for the beneficiary and the costs for the government may vary 3 .

During the period 2014-2017 the scope of state aid in the entire European Union increased from $€ 91.3$ bln to $€ 110.7$ bln [State aid..., 2018]. This trend is not identical in all countries. Examples of countries where this aid was reduced in the period analysed are Greece (in 2017 the value of aid in this country was four times lower than in comparison with 2014) and Latvia. In Poland, the value of state aid increased from $€ 4.7$ bln in 2014 to $€ 7$ bln in 2017, which was connected to the activation of the streams of aid measures from the operational programs partly financed from the EU funds [Raport o pomocy..., 2018, p. 15]. Simultaneously, in terms of the dimension of state aid, Poland occupied fourth position in 2017 and was preceded only by Germany ( $€ 42.3$ bln), France ( $€ 16.8$ bln) and Great Britain ( $€ 8.5$ bln). These four countries in 2017 received approximately $67.4 \%$ of the total value of state aid in the EU.

Poland belongs to a cluster of countries where the relative level of state aid is high - namely the index of the state aid share in GDP in 2017 amounted to 1.51\% and was almost two times higher than in the European Union (table 1, chart 1). The nations with the highest index included: Hungary (2.67\%), Denmark $(1.9 \%)$, Latvia (1.77\%) and the Czech Republic (1.51\%). Adversely, the lowest percentage of state aid in GDP (below 0.5\%) was observed in Ireland (0.23\%), Luxembourg and Greece $(0.29 \%$ in each country), Spain $(0.31 \%)$, Slovakia $(0.32 \%)$, the Netherlands $(0.33 \%)$, Italy $(0.34 \%)$, Great Britain $(0.38 \%)$ and Portugal $(0.45 \%)$. Therefore, both the first and the second group included both the "old" and "new" member states, either more or less developed ones. It may indicate that the value of state aid is affected not only by the size of the economy and its condition, but also by other factors. This conclusion is cautious - its accuracy can be verified by expanding the analysis over a longer time period ${ }^{4}$.

It should also be pointed out that state aid in Poland in 2017 reached a record value - starting from 2000 its highest level was recorded in $2003-€ 5.3 \mathrm{bln}$. Therefore, the value of it varies over time (chart 1).

\footnotetext{
${ }^{3}$ For example, as regards guarantees, the beneficiary avoids the risk connected with it because it is taken by the state. Such risk taken by the state usually ought to be rewarded by an appropriate premium. In the situation where a state renounces either the entirety or part of such premium there occurs both the benefit for the enterprise and the burden for public resources. Therefore, if a state never made any payment under guarantees, there may exist state aid within the meaning of art. 107 item 1 TFUE. This aid is given when the guarantee is granted, but not when it is activated or when payments are made according to the terms of the guarantee [The State..., 2018].

${ }_{4}^{4}$ One should remember that in this case the problem lies in the state aid from the perspective of EU legislative regulations instead of public support as such. As it has been emphasised, if this support is connected with providing services in the public interest or connected with de minimis aid, it is not subject to the law on state aid which, in turn, may lead to the hazards connected with the occurrence of state unreliability. Further on this subject in: [Lissowski, 2017, pp. 23-24].
} 


\section{State aid in Poland and the European Union in the years 2000-2017}

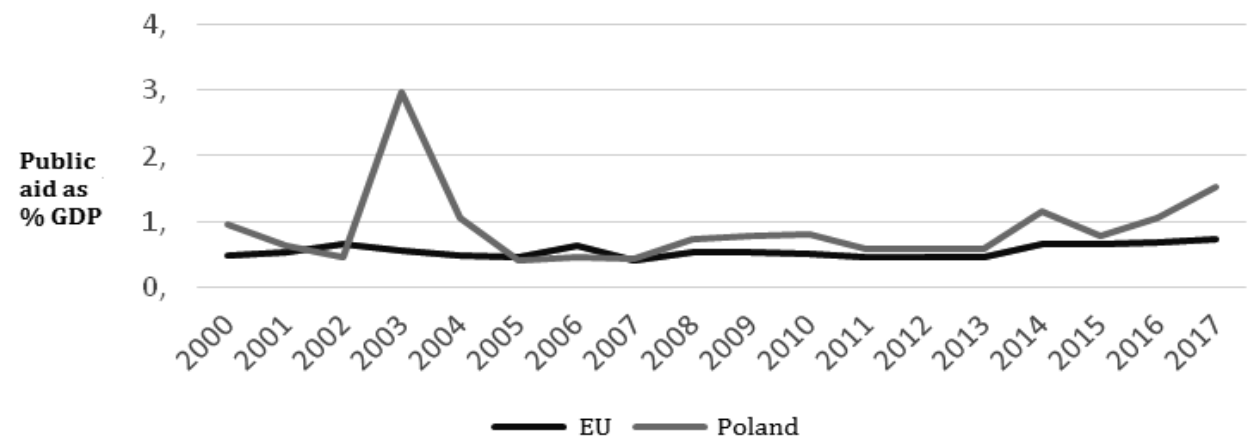

Source: own elaboration based on: [State Aid Scoreboard, 2018].

\section{Directions of state aid distribution}

The European Commission considers as consistent with the domestic market the state aid in areas such as: a) regional aid; b) assistance for SMEs in the form of investment aid, operational assistance and the access of SMEs to financing; c) aid for the natural environmental protection; d) aid for research, development and innovation; e) aid for training; f) aid for the recruitment and employment of workers being in particularly adverse situation and for disabled workers; g) aid aimed at improving the losses caused by some natural disasters; $h$ ) aid of social character in terms of transport for the inhabitants of remote regions; i) aid for broadband infrastructure; j) aid for culture and for the preservation of cultural heritage; $\mathrm{k}$ ) aid for sport infrastructure and multifunctional recreational infrastructure; 1) aid for local infrastructure; m) aid for regional airports; and n) aid for ports [Act, 2014, art. 1].

As underlined in the report evaluating the state aid mechanism, in the early 1990s more than half of aid measures was addressed at supporting the development of sector development and restructuring while in 2017 approx. 94\% of the total expenditure on state aid was allocated for horizontal objectives being the subject of mutual interest [State aid..., 2019] such as: environmental protection (55.4\%), research, development and innovations $(7.9 \%)$ and regional development $(8.9 \%)$ (table 1), which should be assessed in a positive way. Simultaneously, member states have a wide discretion in determining the objectives and ways of realising state aid (naturally while still being compliant with the EU law). As a result, in 15 of them the highest level of expenditures was allocated for environmental protection and lowcarbon economy (on average - more than $60 \%$, where the highest level of aid for that purpose (both in absolute and relative terms) was observed in Germany $85.5 \%$ ). Regional aid was predominant in countries such as: Portugal $(61.9 \%)$, Greece (53.2\%), Croatia (41.8\%), Slovakia (29.5\%) and Hungary (28.1). In Poland, the dominating direction of state aid is also regional policy. - In 2017 every third $€$ 
was allocated for this purpose (table 1). What distinguishes Poland in the entire European Union and in comparison, with other countries is the concentration of funds in four directions: regional policy $(27.3 \%), \mathrm{R} \& \mathrm{D}$ and innovations $(16.7 \%)$, environmental protection (19.8\%) and employment (10.7\%). Owing to such structure of state aid (in comparison with other EU member states) its sustainability is clearly observed and illustrated in chart 2 .

CHART 2

The directions of state aid distribution in Poland and EU in 2017 (in \%)

Poland $\longrightarrow$ EU together

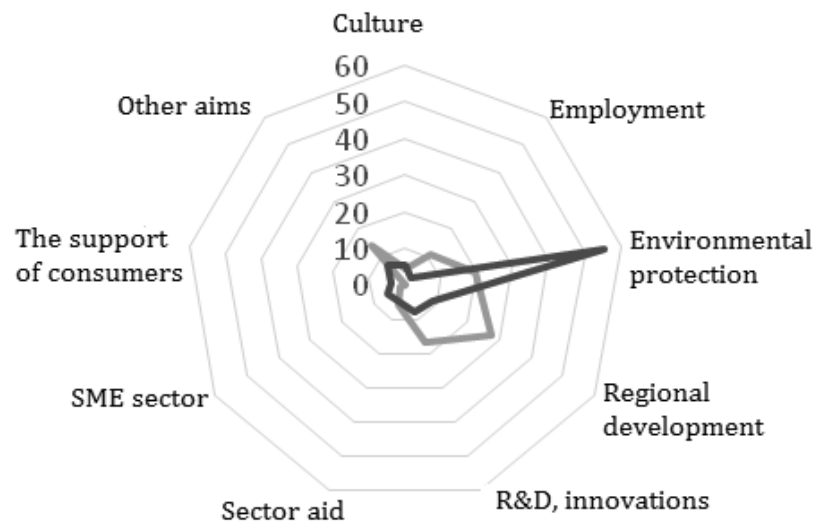

Source: own elaboration based on: [State Aid Scoreboard, 2018].

Among EU member states similar sustainability in the way state aid is distributed can be observed only in France, however the dominating role in this country is played by: environmental protection (26.8\%), the support of consumers (19.1), regional development (16.8\%) and sector aid (14.1\%). 
TABLE 1

\section{The dimension, directions and instruments of state aid in the European Union in 2017}

\begin{tabular}{|c|c|c|c|c|c|c|c|c|c|c|c|c|c|c|c|c|}
\hline \multirow[b]{2}{*}{ Country } & \multirow[b]{2}{*}{ 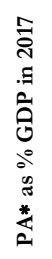 } & \multirow[b]{2}{*}{ 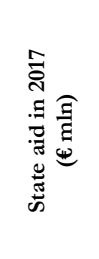 } & \multicolumn{9}{|c|}{ Including directions (in \%): } & \multicolumn{5}{|c|}{ Including instruments (in \%): } \\
\hline & & & $\stackrel{\Xi}{\Xi}$ & 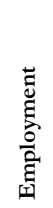 & 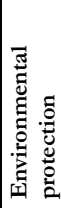 & 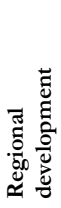 & 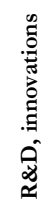 & 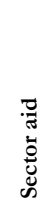 & 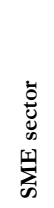 & 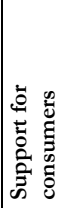 & 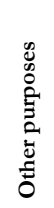 & 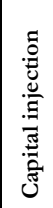 & $\begin{array}{l}\stackrel{0}{7} \\
\frac{0}{5} \\
\frac{0}{3}\end{array}$ & 苞 & 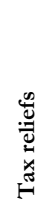 & 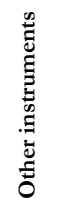 \\
\hline Austria & 0.51 & 1736.6 & 4.0 & 0.0 & 77.0 & 1.4 & 11.2 & 0.6 & 4.2 & 0.0 & 1.6 & 0.0 & 72.4 & 0.6 & 26.9 & 0.7 \\
\hline Belgium & 0.53 & 2204.8 & 21.9 & 5.4 & 4.2 & 5.9 & 36.9 & 8.8 & 5.8 & 0.0 & 11.1 & 7.0 & 53.4 & 0.9 & 37.6 & 0.6 \\
\hline Bulgaria & 1.48 & 662.9 & 1.1 & 0.1 & 78.2 & 20.2 & 0.2 & 0.0 & 0.0 & 0.0 & 0.2 & 0.0 & 24.3 & 0.0 & 7.4 & 68.3 \\
\hline Croatia & 1.23 & 476.3 & 13.3 & 0.8 & 9.7 & 41.8 & 0.2 & 0.9 & 21.7 & 0.0 & 11.6 & 0.0 & 86.9 & 2.3 & 3.5 & 7.3 \\
\hline Cyprus & 0.60 & 104.2 & 33.6 & 0.0 & 52.1 & 0.0 & 0.5 & 13.2 & 0.1 & 0.0 & 0.5 & 0.0 & 88.7 & 0.0 & 11.3 & 0.0 \\
\hline Czech Rep. & 1.51 & 2676.2 & 4.5 & 0.0 & 65.5 & 10.5 & 12.1 & 1.1 & 0.2 & 0.0 & 6.1 & 0.0 & 33.9 & 0.1 & 7.3 & 58.7 \\
\hline Denmark & 1.90 & 4396.8 & 1.6 & 19.8 & 67.2 & 0.3 & 3.2 & 5.9 & 0.7 & 0.0 & 1.3 & 0.3 & 42.9 & 0.2 & 55.7 & 0.9 \\
\hline Estonia & 1.07 & 235.9 & 17.9 & 0.0 & 67.2 & 3.6 & 3.4 & 3.6 & 0.0 & 0.0 & 4.3 & 0.0 & 75.3 & 0.0 & 24.1 & 0.6 \\
\hline Finland & 0.96 & 1821.3 & 2.2 & 2.9 & 71.9 & 3.6 & 7.5 & 5.8 & 2.8 & 0.0 & 3.3 & 0.3 & 45.9 & 0.7 & 52.7 & 0.4 \\
\hline France & 0.76 & 16824.6 & 8.2 & 0.0 & 26.8 & 16.8 & 4.8 & 14.1 & 6.5 & 19.1 & 3.7 & 0.7 & 45.4 & 2.2 & 42.6 & 9.1 \\
\hline Greece & 0.29 & 427.3 & 0.1 & 1.9 & 4.6 & 53.2 & 0.8 & 0.4 & 0.2 & 0.0 & 38.8 & 0.0 & 99.7 & 0.0 & 0.0 & 0.3 \\
\hline Spain & 0.31 & 3023.4 & 6.7 & 1.9 & 4.0 & 6.5 & 10.8 & 18.8 & 2.1 & 22.9 & 26.3 & 0.0 & 66.3 & 4.7 & 28.9 & 0.1 \\
\hline Netherlands & 0.33 & 1962.3 & 6.1 & 0.0 & 58.4 & 0.1 & 14.6 & 12.5 & 1.8 & 0.0 & 6.5 & 0.3 & 82.6 & 3.6 & 12.7 & 4.4 \\
\hline Ireland & 0.23 & 528.3 & 5.1 & 0.0 & 61.4 & 8.9 & 15.6 & 0.0 & 1.8 & 0.0 & 7.2 & 0.0 & 89.6 & 2.4 & 7.6 & 0.4 \\
\hline Lithuania & 1.09 & 441.4 & 44.9 & 6.5 & 31.1 & 9.5 & 2.6 & 2.1 & 0.4 & 0.0 & 2.9 & 0.3 & 37.7 & 0.0 & 24.3 & 37.7 \\
\hline Luxembourg & 0.29 & 149.8 & 4.8 & 0.1 & 60.1 & 0.0 & 22.9 & 0.3 & $1 . .2$ & 0.0 & 1.7 & 0.0 & 99.0 & 0.0 & 0.0 & 1.0 \\
\hline Latvia & 1.77 & 436.3 & 19.9 & 0.0 & 8.9 & 4.6 & 2.9 & 61.2 & 0.1 & 0.0 & 2.4 & 1.6 & 85.9 & 0.7 & 11.7 & 0.1 \\
\hline Malta & 0.79 & 88.6 & 8.2 & 3.2 & 0.7 & 36.9 & 0.2 & 49.1 & 1.0 & 0.0 & 0.7 & 0.0 & 35.9 & 1.9 & 49.2 & 13.0 \\
\hline Germany & $1, .1$ & 42313.2 & 1.1 & 0.0 & 85.5 & 2.7 & 3.1 & 0.3 & 2.5 & 0.0 & 4.8 & 0.0 & 75.5 & 0.3 & 23.9 & 0.3 \\
\hline Poland & $1, .1$ & 7070.7 & 4.4 & 10.7 & 19.8 & 27.3 & 16.7 & 5.7 & 1.4 & 0.0 & 14.0 & 0.2 & 84.9 & 1.7 & 11.9 & 1.3 \\
\hline Portugal & 0.45 & 836.5 & 0.0 & 0.0 & 0.0 & 69.1 & 9.0 & 0.0 & 17.8 & 3.9 & 0.2 & 0.4 & 26.9 & 45.5 & 11.6 & 15.6 \\
\hline Romania & 0.50 & 922.1 & 0.7 & 0.0 & 83.2 & 7.3 & 5.2 & 0.0 & 0.0 & 0.0 & 3.6 & 0.0 & 29.7 & 0.0 & 11.5 & 58.8 \\
\hline Slovakia & 0.32 & 221.5 & 5.8 & 0.3 & 29.5 & 29.5 & 3.1 & 0.0 & 0.0 & 0.0 & 31.8 & 0.0 & 52.9 & 0.0 & 41.4 & 5.7 \\
\hline Slovenia & 0.88 & 367.6 & 2.8 & 26.8 & 49.5 & 5.7 & 9.4 & 0.2 & 1.0 & 0.0 & 4.6 & 0.0 & 65.9 & 0.0 & 33.2 & 0.9 \\
\hline Sweden & 0.91 & 4335.3 & 1.2 & 0.1 & 73.2 & 1.6 & 3.9 & 5.3 & 0.5 & 0.0 & 14.2 & 0.0 & 28.9 & 0.0 & 70.9 & 0.2 \\
\hline Hungary & 2.67 & 3127.5 & 23.1 & 4.1 & 7.7 & 28.1 & 14.0 & 1.4 & 1.4 & 0.0 & 20.2 & 0.9 & 92.2 & 0.2 & 6.6 & 0.1 \\
\hline Great Britain & 0.38 & 8547.6 & 10.3 & 0.1 & 43.8 & 3.9 & 212 & 0.2 & 15.0 & 0.0 & 5.5 & 1.0 & 58.2 & 0.2 & 34.7 & 8.5 \\
\hline Italy & 0.34 & 4746.2 & 5.1 & 7.4 & 18.8 & 10.7 & 11.6 & 3.2 & 32.6 & 0.0 & 10.6 & 0.0 & 58.3 & 3.9 & 26.8 & 11.0 \\
\hline UE together & 0.76 & 110685.0 & 5.1 & 2.3 & 55.4 & 8.9 & 7.9 & 4.6 & 5.2 & 3.6 & 7.0 & 0.4 & 63.9 & 1.3 & 29.3 & 5.1 \\
\hline
\end{tabular}

* State aid

Source: own elaboration based on: [State Aid Scoreboard, 2018]. 


\section{State aid instruments}

As it has already been emphasised, state aid constitutes either the expenditure or loss of income for public authorities and the benefit for recipients. However, the element of aid, i.e. the ultimate financial benefit included in the nominal sum submitted to the beneficiary depends, to a large degree, on the form in which aid is provided. To make a comparison of these benefits possible, the calculation of them is made into the so-called gross subsidy equivalent. It is the actual economic advantage achieved by an entrepreneur in a certain form of aid ${ }^{5}$.

In principle, member states of the European Union provide aid by means of four groups of instruments: subsidies and tax reliefs, capital injection, preferential loans as well as guarantees and sureties. The data presented in table 1 shows that more than $93 \%$ of state aid is given to businesses by means of subsidies (63.9\%) and tax reliefs $(29.3 \%)$. A subsidy (including a refund or compensation) is the most transparent form of aid. In practice, it relates to the transfer of budget funds to the beneficiary. This instrument is most preferably used in most EU member states. In such states as Greece or Luxembourg it regards almost $99 \%$ of aid measures (table 1). In Poland almost $85 \%$ of aid measures are implemented using subsidies (chart 3). A positive aspect of using them is the release of own funds of the beneficiary (in 2017: 61\% of the value of state aid in Poland was eligible for co-financing while in the EU it was on average 11\%) [State aid..., 2018].

CHART 3

State aid instruments in Poland and EU in 2017 (in \%)

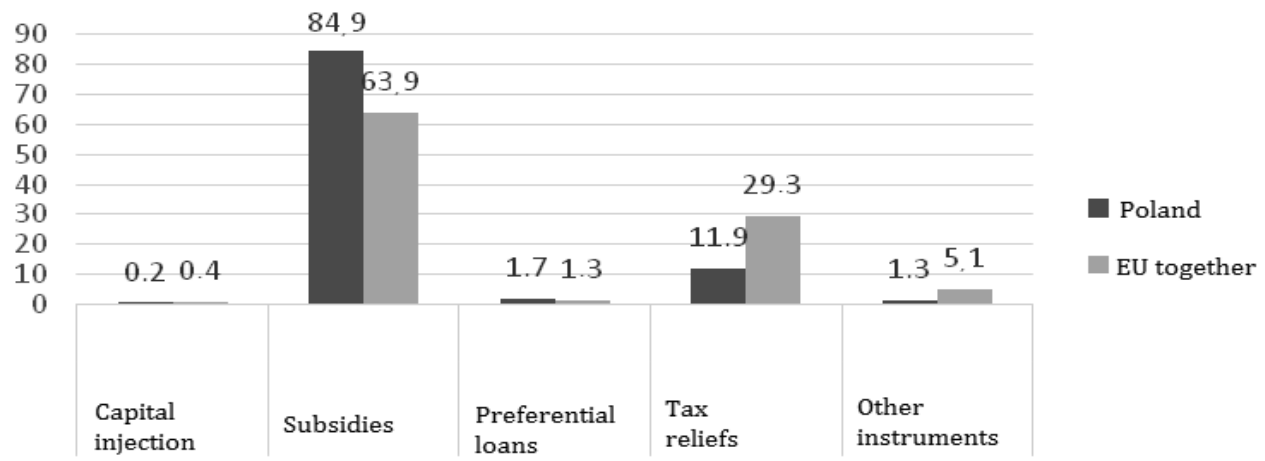

Source: own elaboration based on: [State Aid Scoreboard, 2018].

Tax reliefs have an entirely different character. This term denotes such instruments as: tax exemption, tax deduction, reduction of decrease causing the lowering of the tax base or of the tax value, reduction in the value of the payment, the

\footnotetext{
5 This mechanism regulated by the Regulation of the Council of Ministers of 11 August 2004 on detailed method of calculating the value of state aid granted in various forms [Act, 2004].
} 
exemption from the payment, the discontinuance of tax collection, the write off of all or part of the tax debt including plus interest, etc. In comparison with subsidies, tax reliefs have an entirely different commercial substance. Firstly, they constitute the loss or the resignation from the part of incomes due to the state. Secondly, in general, they may be used by those businesses that will achieve economic surplus. Therefore, this instrument encourages an economic activity. In Poland, the share of tax reliefs in financing state aid in 2017 was three times lower than it is on average in the EU and it amounted to $11.9 \%$ (table 1, chart 3). It is worth emphasising that this instrument is extremely popular in all Scandinavian countries - in 2017 its share was higher than 50\%, while in Sweden it amounted to as much as $70 \%$.

Other forms of financing state aid have rather marginal importance. Across the EU they are not higher than $7 \%$ of the total value of this aid.

\section{Conclusions}

The considerations presented in this paper imply that the European Union as a general rule protects the mechanism of market competition, by determining the principles of the way the EU market ought to function. State aid used by EU member states as a form of intervention must comply with the mutual market and must not distort competition. The analysis of the dimension, directions, and instruments of state aid (with the exclusion of the sectors of transport and agriculture) used in 2017 in Poland in comparison with European Union member states enables the formulation of several conclusions.

1. In the scale of the entire European Union, between 2014-2017 the value of state aid was increasing both in absolute and relative terms, while in 2017 it constituted $0.76 \%$ GDP. In Poland in 2017 it amounted to more than $€ 7$ bln euro $(1.51 \%)$, owing to which Poland occupied the fourth position. It is worth emphasising that it has never been so high (its highest level was recorded in $2003-€ 5.3$ bln).

2. In the European Union there is clearly observed the dominating concentration of aid measures on environmental protection (55\%), while in Poland the main direction of state aid is regional development, of which there was allocated more than $27 \%$ of aid measures in 2017. As regards the share in public support not less important areas are: environmental protection (19.8\%), $\mathrm{R} \& \mathrm{D}$ and innovations $(16.7 \%)$ and employment $(10.7 \%)$ which are included into the so-called horizontal aid.

3. Therefore, one may assume that the structure of state aid directions in Poland in comparison with other European Union is clearly different and is characterised by their sustainability.

4. In financing state aid, a key role is played by subsidies and tax reliefs. In Poland, the share of subsidies in 2017 amounted to $85 \%$ and it was by approx. 20 p.p. higher than it is on average in the EU. Adversely, the share of tax reliefs did not exceed 12\%, while in the EU it amounted to $30 \%$. 
Although these differences are clear, they are not the evidence of considerable difference in comparison with other states because the universal practice of member states is the applications of the aforementioned two instruments during the implementation of state aid.

With reference to the thesis formulated in the introduction, it can be concluded that it was only partly verified in a positive way. Namely, in the relative perspective, the value of state aid in Poland is high in the context of other countries of the European Union, while in 2017 it was about twice its average level in the EU. Additionally, in terms of state aid, Poland differs from other EU member states due to the sustainability connected with the directions of distributing it. Meanwhile, what was not confirmed was the occurrence of considerable differences in terms of the state aid instruments that was being used.

In summary, it is worth noting that state aid is an important instrument of state intervention. Although (as the presented data implies) its value in the entire European Union does not exceed $0.8 \%$ GDP (with the exception of the sectors of transport and agriculture), it is solely a part of considerably greater public support that goes beyond the formal regulations from the domain of state aid. Despite the discussion (which has been led by economists for many years) on the effectiveness of the money spent by the government, this support plays an essential role in particular moments of economic development: crisis, transformation, restructuring, etc. The paper is being compiled during an unusual and unique moment: when coronavirus is spreading worldwide (including in Europe and Poland) and when the negative effects of the pandemic will go far beyond the issues of public health. Economic slowdown can be observed presently, while the future prospects are very pessimistic. In such circumstances the expectations regarding the activity and involvement of state are still increasing. In the second half of March 2020 the European Commission announced the proposals of changes in the regulations concerning state aid of member states. Apart from the confirmation that the current situation is exceptional and satisfies the provisions excluding the prohibition of state aid, there were announced four assumptions of legislative proposals [www 1]. Furthermore, the European Commission provided member states with additional measures in their fight against the pandemic, enabled the purchase of medical supplies, equipped hospitals and offered support programs for small and mediumsized enterprises and also initiated short-term programs to support employment. From the total sum of $€ 37.3 \mathrm{bln}$, Poland will receive $€ 7.4$ bln [www 2]. It is highly likely that it will be solely a fraction of money that should be spent on saving economies and the purposes of distributing the money will be subject to considerable transformation. 


\section{References}

Act, 2004, Rozporządzenie Rady Ministrów z dnia 11 sierpnia 2004 r. w sprawie szczegółowego sposobu obliczania wartości pomocy publicznej udzielanej w różnych formach, 2004, Dz. U. z 2018 r. poz. 461.

Act, 2013, Rozporządzenie Komisji (UE) nr 1407/2013 z dnia 18 grudnia 2013 r. w sprawie stosowania art. 107 i 108 Traktatu o funkcjonowaniu Unii Europejskiej do pomocy de minimis, 2013, Dz. U. L 352/1 z 24.12.2013.

Act, 2014, Rozporządzenie Komisji (UE) nr 651/2014 z dnia 17 czerwca 2014 r. uznające niektóre rodzaje pomocy za zgodne $\mathrm{z}$ rynkiem wewnętrznym w zastosowaniu art. 107 i 108 Traktatu, 2014, Dz. U. L 187 z 26.06.2014 z późn. zm.

Guide to the application of the European Union rules on state aid, public procurement and the internal market to services of general economic interest, and in particular to social services of general interest, 2013, https://ec.europa.eu/competition/state_aid/overview/new_ guide_eu_rules_procurement_en.pdf [date of entry: 05.03.2020].

Kogut-Jaworska M., 2016, Pomoc publiczna i jej szczególne znaczenie w systemie wsparcia publicznego w Polsce, „Prace Naukowe Uniwersytetu Ekonomicznego we Wrocławiu", nr 415, s. 187-197, DOI: 10.15611/pn.2016.451.15.

Konstytucja Rzeczpospolitej Polskiej z dnia 2 kwietnia 1997 r., 1997, Dz. U. z 1997 r., nr 78, poz. 483 z późn. zm.

Lissowski O., Ustugi publicżne $i$ ustugi w interesie ogólnym - koncepcja i niektóre problemy instytucjonalne marketyzacyjnej modernizacji swiadcrenia ustug publicznych w Unii Europejskiej, 2017, „Zeszyty Naukowe Politechniki Poznańskiej - Organizacja i Zarządzanie", nr 74, s. 9-27, DOI: 10.21008/j.0239-9415.2017.074.01.

Przygodzka R., Rola sektora publicznego we wspótczesnych procesach rozwojonych, „Optimum. Studia Ekonomiczne", 2009, nr 4(44), s. 51-62.

Raport o pomocy de minimis w Polsce udrielonej przedsiębiorcom w 2017 roku, 2018, Urząd Ochrony Konkurencji i Konsumenta, Warszawa.

Raport o pomocy publicznej w Polsce udrielonej przedsiebiorcom w 2017 r., 2018, Urząd Ochrony Konkurencji i Konsumenta, Warszawa.

Rezolucja Parlamentu Europejskiego z dnia 17 stycznia 2013 r. w sprawie unowocześnienia polityki w dziedzinie pomocy państwa, 2013, (2012/2920(RSP).

State Aid Scoreboard 2018: Results, trends and observations regarding EU28 State Aid expenditure reports for 2017, 2019, European Commission, Brussels, https://ec. europa.eu/competition/state_aid/scoreboard/state_aid_scoreboard_2018.pdf [date of entry: 10.03.2020].

State Aid Scoreboard, 2018, https://ec.europa.eu/competition/state_aid/scoreboard/ index_en.html [date of entry: 27.02.2020]

TFUE, 2016, Traktat o funkecjonowaniu Unii Europejskiej (wersja skonsolidowana), Dz. Urz. UE 2016, c 202/1.

The 2018 Scoreboard - Concepts and methodology, 2018, https://ec.europa.eu/competition/state_aid/scoreboard/index_en.html [date of entry: 27.02.2020].

TUE, 2016, Traktat o Unii Europejskiej (wersja skonsolidowana), Dz. Urz. UE 2016, C 202/13. 
www 1, https://alebank.pl/ke-lagodzi-przepisy-o-pomocy-publicznej [date of entry: 09.04.2020].

www 2, https://www.politykazdrowotna.com/55331,polska-gigantycznym-beneficjentem-ue-w-walce-z-koronawirusem [date of entry: 18.03.2020]. 